\section{THE FLYING MAN}

$T^{H}$ HE fatal experiment made by $M$. de Groof at Cremorne Gardens could not possibly have led to success. The possibility of directing an apparatus in the air by any mechanical contrivance, without actually using the lifting power of gas, is out of the question, and we do not wish to enter into a discussion on that point. But several interesting problems may be examined $\dot{a}$ propos of the inquest held by the coroner on the death of the unfortunate man.

De Groof's wings, irrespective of their motive power, may be regarded as two imperfect parachutes intended to diminish his rate of falling, and, if kept horizontal, prevent it increasing above a certain rate. It remains to see if their surface was large enough to keep that velocity within reasonable limits. The wings of $\mathrm{De}$ Groof were $30 \mathrm{ft}$. by $4 \mathrm{ft}$; ; but being irregularly shaped, we may suppose the surface of each was 1oo sq. $\mathrm{ft}$., or in round numbers $200 \mathrm{sq}$. ft. for the two. The weight of the machine not being far from $4 \mathrm{cwt}$, if we include the man, we may say in gross numbers that each square foot had a kilogramme to support, which is mare than ordinary; the parachute maker taking I kilogramme for each square metre, which is about ten times smaller.

But to ascertain if the velocity, although being larger than under ordinary circumstances, was really dangercus we must go to the formula established by General Didion and quoted by Poucelet-

$$
R=\mathrm{I}^{\circ} 936\left(A 0^{\circ} 036+0.0840^{3}\right)
$$

Under the above circumstances, 蟔 the rate of falling is always inferior to the value of $x$ given by the equation

$$
\text { Io }=x .936\left(0.036+0.084 x^{-3}\right)
$$

$x$ being obviously enough the velocity for which $R=$ to the weight pressing on the unit of surface. When the motion is such the velocity cannot be increased. If we make the calculation it is easy to see that the velocity is about 7 metres per second, almost $=$ the fall from 3 metres to the ground. It is large, but not too large for a practised jumper, if he were clever enough to keep his balance, which is not very easy, it must be confessed.

Experiments on parachutes show that great oscillations always take place if the experimenters have not placed a small hole in the centre of their parachute, which increases stability at the expense of resistance. The motion of the wings, if they are workin together, would very likely render the same service to the occupant of the machine, as they prevent the accumulation of the air. Unfortunately, to keep them working evenly is a difficult matter, requiring not only force of muscle but great presence and firmness of mind. The so-called quene or rudder was a useless encumbrance. A man working hard with his two hands, fighting for his life, cannot be expected to attend to direction with his legs attached to a rudder. The lifting power of the wings must have been very small indeed, although diminishing in some respects the rate of falling; but it is not easy to understand how a calculation may be made of the amount of mechanical power exerted in each stroke. The question must be left open for future examination.

W. DE FONVIELLE

\section{NOTES}

A CIRCULAR has been isstied by the Hon. Local Secretaries of the Belfast meeting of the British Association, calling attention to the numerous objects of interest, natural and mechanical, with which the town and neighbourhood of Belfast, as well as the county of Antrim, abounds. The whole Province of Ulster is full of objects of the highest interest to the admirer of natural scenery, to the geologist, the naturalist, and the antiquarian; and many of its most interesting localities, such as the Antrim Coast, the Giant's Causeway, the Mourne Mountains, Lough Neagh, the Round Towers of Antrim and Drumbo, are within an easy distance of Belfast. The local secretaries state that a large number of the hotels will be open to members of the Association at the usual charges, and that a list of persons willing to let rooms has been prepared. We sincerely hope that this time there will be no complaint to make on the score of accommodation. Conveyance to Belfast can be obtained from any part of the country at very reasonable rates.

THE Right Hon. Lord O'Hagan will preside over the Section for Economic Science at the meeting of the British Association.

A meting of the General Council of the Yorkshire College of Science was held at Leeds on the I 1 th inst. The Council proceeded to the election of the Professor of Geology and Mining, and the Professor of Physics and Mathematics. The vote of the Council was unanimously given to Mr. A. H. Green, M.A., late Senior Fellow of Gonville and Caius College, Cambridge, as Professor of Geology; and Mr. A. W. Rücker, M.ł., Fellow of Brasenose College, Oxford, as Professor of Physics and Mathematics. Prof. Green for the last five years has held the appointment of Lecturer on Geology at the School of Military Engineering at Chatham. Prof. Rücker in Oct. I87r was appointed Demonstrator in the Physical Laboratory of Oxford University under Prof. Clifton. The appointment of the Professor of Chemistry will be made on Friday. The Council recorded a cordial vote of thanks to Sir A. Fairbairn for his liberal offer of $2,000 l$, , provided that the sum of $60,000 \%$. was placed in the hands of the treasurer, and resolved to take the necessary steps for raising the required amount.

At King's College, London, the Chair of Zoology and Comparative Anatomy, vacated by the resignation of Prof. T. Rymer Jones, F.R.S., has been filled by the election of Mr. A. H. Garrod, Fellow of St. John's College, Cambridge, and Prosector to the Zoological Society. The Chair of Materia Medica and Therapeutics, vacated by the resignation of Prof. A. B. Garrod, M.D., F.R.S., has been filled by the election of Dr. E. B. Baxter, Medical Tutor to the College.

THE prospectus has just been issued of a company to establish an aquarium for London, close to Westminster Abbey.

A BALLOON experiment to test a steering apparatus is soon to be made under the auspices of the authorities at Woolwich.

Northumberland, in Pennyslvania, on the Susquehannah, the place where Dr. Priestley was buried, has been selected by Americans as the spot at which all chemists are invited to gather on August I next, the hundredth anniversary of the discovery of oxygen by the illustrious philosopher. An address is to be delivered over his grave. This proposition of Dr. Bolton has met with a cordial response from a large number of chemists. Prof. Henry, of the Smithsonian Institution, proposes to be present with some of the original apparatus of Friestley from the Smithsonian collections. August I falling on Saturday, the meeting will be called for the day previous. A programme will be soon issued by the committee in charge.

THE Governing Body of Christ Church, Oxford, have yoted the sum of $100 /$. per annum for five years in aid of the Biological Department of the Museum.

The New Falcons' Aviary in the northern part of the Zoological Society's Gardens beyond the canal has just been completed, and is now tenanted by a fine series of the Diurnal Birds of Prey, principally exotic. Amongst them are examples of several rare species, such as the Red-backed Buzzard (Buteo erythro. notus), the Laughing Eagle (Herpetothires cachinnarus), and the Malayan Crested Eagle (Spizaetus caligatus). Amongst the less. known European species are a pair of Bonelli's Eagles, a pair of Red-footed Falcons, and an Eleonora Falcon. 